\title{
Efektivitas Penerapan Model Kooperatif STAD Berbasis Multimedia untuk Meningkatkan Penguasaan Siswa SMA terhadap Kemampuan yang Diujinasionalkan Mata Pelajaran Fisika di Maluku Utara
}

\author{
Saprudin
}

\begin{abstract}
Abstrak
Penelitian ini bertujuan untuk menyelidiki efektifitas penerapan model kooperatif STAD berbasis multimedia untuk meningkatkan penguasaan siswa SMA terhadap kemampuan yang diujinasionalkan pada mata pelajaran fisika di provinsi Maluku Utara. Metode penelitian yang digunakan adalah metode eksperimen dengan desain randomized control group pretest-posttest design. Sampel dalam penelitian ini adalah siswa kelas X semester genap tahun ajaran 2014/2015 pada salah satu SMA di Kabupaten Halmahera Timur Provinsi Maluku Utara. Berdasarkan hasil analisis statistik disimpulkan bahwa pembelajaran dengan menerapkan model kooperatif STAD berbasis multimedia lebih efektif dalam meningkatkan penguasaan siswa pada kemampuan yang diujinasionalkan dibandingkan dengan pembelajaran kooperatif STAD tanpa penggunaan multimedia interaktif dan pembelajaran konvensional.
\end{abstract}

Kata Kunci: Model kooperatif STAD, Multimedia Interaktif, Ujian Nasional

\section{Pendahuluan}

Ujian Nasional (UN) merupakan kegiatan pengukuran kompetensi tertentu yang dicapai peserta didik dalam rangka menilai pencapaian standar nasional pendidikan yang dilaksanakan secara nasional [1]. Salah satu mata pelajaran yang secara umum masih dianggap sulit untuk dikerjakan oleh siswa SMA adalah mata pelajaran fisika [2].

Berdasarkan hasil analisis dokumentasi hasil ujian nasional mulai tahun ajaran 2007/2008 sampai 2011/2012 menunjukkan bahwa daya serap siswa terhadap mata pelajaran fisika di provinsi Maluku Utara belumlah memuaskan, seperti ditunjukkan pada Tabel 1.

Tabel 1. Rekapitulasi Daya Serap Siswa Pada UN Mata Pelajaran Fisika SMA Program IPA

\begin{tabular}{|c|c|c|c|c|c|}
\hline \multirow{3}{*}{ Kab/ Kota } & \multicolumn{5}{|c|}{ Rerata NIIal UN } \\
\hline & $200 \pi$ & 20081 & 20091 & 20101 & 20111 \\
\hline & 2008 & 2009 & 2010 & 2011 & 2012 \\
\hline Ternate & 6,32 & $5,5 /$ & 5,58 & 6,61 & 8,55 \\
\hline I Idore Kepulauan & 6,44 & b,by & 5,46 & 6,34 & 6,50 \\
\hline Halmahera Barat & 6,35 & 4,98 & 5,12 & b, ५4 & 1,30 \\
\hline Halmahera Utara & 6,13 & $b, 2 b$ & b,bu & 1,24 & b,b5 \\
\hline Halmahera Selatan & $6,2 b$ & 6,00 & $b, 22$ & 6,35 & 1,12 \\
\hline Halmahera Tengah & 6,17 & 4,66 & 4,65 & 6,82 & 8,09 \\
\hline Halmahera Iımur & 6,05 & 3,83 & 6,33 & 6,50 & 6,39 \\
\hline Kepulauan Sula & 5,61 & $5,8 /$ & 6,01 & 6,11 & $1, \mathrm{b1}$ \\
\hline Kepulauan Morotai & - & - & 3,74 & 7,30 & 6,74 \\
\hline Rerata Provinsi & 6,19 & 5,57 & 5,43 & 6,48 & 7,37 \\
\hline
\end{tabular}

$[2,3,4,5,6,7]$

Berdasarkan hasil Focus Group Discussion pada SMA sampel di Provinsi Maluku Utara pada kegiatan PPMP tahun 2011 ditemukan bahwa salah satu penyebab lemahnya penguasaan siswa pada kemampuan yang diujinasionalkan pada mata pelajaran fisika adalah kurang optimalnya penggunaan dan juga ketersedian multimedia dalam menunjang penguasaan konsep fisika yang abstrak. $[2,8,9$, $10,11,12]$

Hasil penelitian Saprudin, dkk (2014) menunjukkan bahwa penggunaan multimedia interaktif dalam pembelajaran fisika lebih dapat meningkatkan kompetensi siswa SMA pada kompetensi yang diujinasionalkan dibandingkan dengan pembelajaran konvensional [2].

Namun pada kenyataannya, penggunaan multimedia dalam pembelajalan tentunya memerlukan fasilitas dan sarana yang mendukung. Penggunaan multimedia biasanya mengalami hambatan ketika diimplementasikan pada sekolah yang fasilitasnya dikategorikan kurang atau tidak memadai.

Sehubungan dengan hal tersebut, masih ditemukan sekolah SMA di Provinsi Maluku Utara yang berada di daerah dengan fasilitas listrik dan juga sarana komputer yang belum memadai. Oleh karena itu, sangatlah perlu dilakukan penelusuran mengenai strategi implementasi multimedia interaktif yang dikembangkan pada SMA yang berada pada daerah tersebut.

Salah satu model pembelajaran yang dapat diterapkan untuk menjembatani permasalahan di atas adalah model pembelajaran kooperatif Students Teams Achievement Divisions (STAD). Penelitian ini bertujuan untuk menyelidiki efektifitas penerapam model kooperatif Students Teams Achievement Divisions (STAD) berbasis multimedia interaktif untuk meningkatkan 
penguasaan siswa SMA terhadap kemampuan yang diujinasionalkan pada mata pelajaran fisika.

\section{Teori}

\section{A. Multimedia Interaktif}

Hofstetter menyebutkan bahwa multimedia merupakan pemanfaatan komputer untuk menggabungkan teks, grafik, audio, gambar bergerak (video dan animasi) menjadi satu kesatuan dengan link dan tool yang tepat sehingga memungkinkan pemakai multimedia dapat melakukan navigasi, berinteraksi, berkreasi dan berkomunikasi [13]. Sejalan dengan hal itu, Vaughn menjelaskan bahwa multimedia merupakan kombinasi dari teks, grafik, suara, animasi dan video yang disampaikan dan dikontrol dengan komputer [14]. Seiring dengan perkembangan teknologi yang semakin pesat, Thomson mendefinisikan multimedia sebagai suatu sistem yang menggabungkan gambar, video, animasi, suara secara interaktif [15].

Dari definisi-definisi tersebut nampaknya ada kesamaan bahwa teknologi multimedia mencakup berbagai media dalam satu software pembelajaran yang interaktif. Sajian multimedia dapat diartikan sebagai teknologi yang mengoptimalkan peran komputer sebagai media yang menampilkan teks, suara, grafik, video, animasi dalam sebuah tampilan yang terintegrasi dan interaktif [15].

Multimedia dapat digunakan dalam kegiatan belajar mengajar karena memiliki beberapa keunggulan di antaranya; a) Interaktif, b) memberikan iklim afeksi secara individual, c) meningkatkan motivasi belajar, d) memberikan umpan balik dan e) kontrol pemanfaatannya sepenuhnya ada pada pengguna. Di samping keunggulan, multimedia interaktif ini juga memiliki kelemahan diantaranya; a) pengembangannya memerlukan adanya tim yang profesional dan b) pengembangannya memerlukan waktu yang cukup lama [16].

\section{B. Model Pembelajaran Kooperatif Students Teams Achievement Divisions (STAD)}

Johnson \& Johnson (1994) menyatakan bahwa belajar kooperatif merupakan kegiatan belajar mengajar secara kelompok-kelompok kecil, siswa belajar dan bekerja sama untuk sampai kepada pengalaman belajar yang optimal, baik pengalaman individu maupun pengalaman kelompok [17].

Dalam kooperatif Students Teams Achievement Divisions (STAD) para siswa dibagi dalam tim belajar yang terdiri atas empat orang yang berbeda-beda tingkat kemampuannya, jenis kelamin dan latar belakang etniknya. Guru menyampaikan pelajaran, lalu siswa bekerja dalam tim mereka untuk memastikan bahwa semua anggota tim telah menguasai pelajaran. Selanjutnya semua siswa mengerjakan kuis mengenai materi secara sendiri-sendiri dimana saat itu mereka tidak diperbolehkan untuk saling membantu. Siswa selanjutnya akan mengumpulkan poin untuk tim mereka berdasarkan tingkat kenaikan skor kuis mereka dibandingkan dengan skor awal mereka. Setiap tim akan mendapatkan sertifikat atau bentuk penghargaan yang lain apabila skor rata-rata mereka mencapai kriteria tertentu [18].

Students Teams Achievement Divisions (STAD) merupakan salah satu metode yang paling sederhana dan merupakan model yang paling baik untuk permulaan bagi para guru yang baru menggunakan pembelajaran kooperatif. Students Teams Achievement Divisions (STAD) terdiri atas lima komponen utama yakni; Presentasi kelas, tim, kuis, skor kemajuan individu dan rekognisi tim [18].

\section{Metode Penelitian}

Peneitian ini merupakan penelitian eksperimen dengan desain randomized control group pretest-posttest design.

Tabel 2. Desain Penelitian

\begin{tabular}{|c|c|c|c|}
\hline Group & Pretest & Treatment & Postest \\
\hline $\begin{array}{l}\text { First Exp. Group } \\
\mathrm{R}_{1}\end{array}$ & $\mathrm{~T}_{1}$ & $\begin{array}{c}\text { Model } \\
\text { kooperatif } \\
\text { STAD Berbasis } \\
\text { Multimedia }\end{array}$ & $\mathrm{T}_{2}$ \\
\hline $\begin{array}{c}\text { Second Exp. } \\
\text { Group } R_{2}\end{array}$ & $\mathrm{~T}_{3}$ & $\begin{array}{c}\text { Model } \\
\text { Kooperatif }\end{array}$ & $\mathrm{T}_{4}$ \\
\hline $\begin{array}{c}\text { Control Group } \\
\mathrm{R}_{3}\end{array}$ & $\mathrm{~T}_{5}$ & Konvensional & $\mathrm{T}_{6}$ \\
\hline
\end{tabular}

Sampel dalam penelitian ini adalah siswa kelas $X$ pada salah satu SMA di Kabupaten Halmahera Timur Provinsi Maluku Utara.

Pengumpulan data dilakukan melalui tes yakni uji kompetensi siswa yang berisi kemampuan yang diuji nasionalkan khususnya pada materi kalor. Analisis data dilakukan dengan analisis statistik parametrik. 


\section{Hasil dan diskusi}

A. Deskripsi Peningkatan Penguasaan Siswa terhadap Kemampuan yang Diujinasionalkan Mata Pelajaran Fisika

Peningkatan penguasaan siswa terhadap kemampuan yang diujinasionalkan baik pada kelas eksperimen ke-1, kelas eksperimen ke-2 maupun kelas kontrol dapat ditelusuri dari perolehan skor sebelum (pretest) dan setelah siswa mengikuti pembelajaran (posttest).

Adapun hasil pretest, posttest dan N-gain siswa dapat ditunjukkan pada Tabel 3.

Tabel 3. Rata-rata Skor Pretest, Posttest dan Ngain Hasil Uji Kompetensi Siswa

\begin{tabular}{lcccc}
\hline \multirow{2}{*}{ Kelas } & Tes & $\mathrm{X}_{\text {ideal }}$ & $\bar{X}$ & N-gain \\
& & & & \\
\hline Eksperimen ke 1 & Pretest & 100 & 20 & \multirow{2}{*}{0,60} \\
& Posttest & 100 & 68 & \\
Eksperimen ke 2 & Pretest & 100 & 25 & \multirow{2}{*}{0,43} \\
& Posttest & 100 & 57 & \\
Kontrol & Pretest & 100 & 17 & \multirow{2}{*}{0,35} \\
& Posttest & 100 & 46 & \\
\hline
\end{tabular}

Persentase pencapaian skor rata-rata pretest, posttest dan gain skor yang dinormalisasi ( $\mathrm{N}$ gain) untuk hasil uji kompetensi siswa ditunjukkan pada gambar 1.

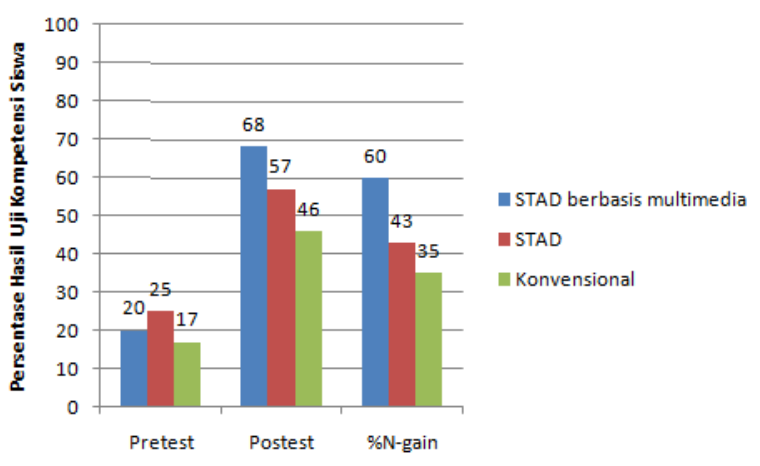

Gambar 1

Perbandingan persentase skor rata-rata pretest, posttest dan $\mathrm{N}$-gain

Berdasarkan gambar 1 di atas terlihat bahwa penguasaan siswa pada kemampuan yang diujinasionalkan mengalami peningkatan setelah mengikuti pembelajaran baik pada kelas eksperimen ke 1 yakni kelas yang diberi perlakuan penerapan model kooperatif Students Teams Achievement Divisions (STAD) berbasis multimedia, kelas eksperimen ke 2 yakni penerapan model kooperatif Students Teams Achievement Divisions (STAD) tanpa penggunaan multimedia maupun pada kelas kontrol yakni pembelajaran konvensional.

Untuk melihat besarnya peningkatan penguasaan siswa pada kemampuan yang diujinasionalkan, kita dapat membandingkan besarnya rata-rata $\mathrm{N}$-gain pada ketiga kelas tersebut. Rata-rata nilai $\mathrm{N}$-gain pada kelas eksperimen ke 1 sebesar 0,60 (sedang), kelas eksperimen ke 2 sebesar 0,43 (sedang) dan untuk kelas kontrol sebesar 0,35 (sedang). Berdasarkan hal tersebut dapat dinyatakan bahwa rata-rata $\mathrm{N}$-gain untuk kelas eksperimen ke 1 lebih tinggi dari pada kelas eksperimen ke 2 dan kelas kontrol.

\section{B. Hasil Uji Statistik}

Uji normalitas dengan menggunakan OneSample Kolmogorov-Smirnov Test dan uji homogenitas varian dengan menggunakan Levene Tes (Test of Homogeneity of Variances) menunjukkan bahwa data hasil uji kompetensi siswa pada ketiga kelas berdistribusi normal dan homogen.

Setelah diketahui bahwa data pada ketiga kelas berdistribusi normal dan homogen maka selanjutnya dilakukan uji statistik parametrik (uji anova satu jalur dengan $\alpha=0,05)$. Dengan menggunakan One-way ANOVA Test diperoleh nilai $F_{\text {hitung }}=9,782$ yang lebih besar dari $F_{\text {tabel }}$ $(0.05,2,62)=3,15$.

Berdasarkan pada nilai $\mathrm{N}$-gain dan hasil analisis dari uji ANOVA satu jalur dapat disimpulkan bahwa penerapan model kooperatif Students Teams Achievement Divisions (STAD) berbasis multimedia interaktif secara signifikan lebih dapat meningkatkan penguasaan siswa pada kemampuan yang diujinasionalkan dibandingkan dengan pembelajaran kooperatif Students Teams Achievement Divisions (STAD) tanpa penggunaan multimedia dan pembelajaran konvensional.

\section{Kesimpulan}

Berdasarkan hasil analisis data disimpulkan bahwa penerapan model kooperatif Students Teams Achievement Divisions (STAD) berbasis multimedia interaktif secara signifikan lebih dapat meningkatkan penguasaan siswa SMA pada kemampuan yang diujinasionalkan dibandingkan dengan pembelajaran kooperatif Students Teams Achievement Divisions (STAD) tanpa penggunaan multimedia dan pembelajaran konvensional.

\section{Ucapan terima kasih}

Penulis mengucapkan terima kasih kepada DP2M Dikti, LPPM Unkhair, Kepala sekolah dan tim pengambil data di SMAN 2 Halmahera Timur, IbIKK Edu.Com-Preneur. 


\section{Referensi}

[1] Peraturan Menteri Pendidikan Nasional Republik Indonesia Nomor 66 Tahun 2013 Tentang Standar Penilaian Pendidikan.

[2] Saprudin, dkk. (2014). Pengembangan Model Multimedia Pembelajaran Fisika Berorientasi Peta Kompetensi Siswa Sekolah Menengah Atas (SMA) di Provinsi Maluku Utara (Laporan Penelitian PEKERTI). LPPM UNKHAIR : tidak diterbitkan

[3] BSNP, Puspendik, Balitbang Depdiknas. (2008). Laporan Hasil Ujian Nasional Tahun 2007/2008 (Software). Depdiknas.

[4] BSNP, Puspendik, Balitbang Depdiknas. (2009). Laporan Hasil dan Statistik Nilai Ujian Nasional Tahun Pelajaran 2008/2009 (Software). Depdiknas

[5] BSNP, Puspendik, Balitbang Depdiknas. (2010). Laporan Hasil Ujian Nasional Tahun Pelajaran 2009/2010 (Software). Depdiknas

[6] BSNP, Puspendik, Balitbang Kemdiknas. (2011). Laporan Hasil Ujian Nasional Tahun Pelajaran 2010/2011 (Software). Kemdiknas.

[7] BSNP, Puspendik, Balitbang Kemdikbud. (2012).Laporan Hasil Ujian Nasional Tahun Pelajaran 2011/2012 v.1 (Software). Kemdikbud.

[8] Dharmawathy dkk. (2011). Pemetaan Kompetensi dan Pengembangan Mutu Pendidikan SMAdi Kabupaten Halmahera Barat, Halmahera Utara dan Kepulauan Morotai (Laporan Penelitian). LPPM Unkhair : tidak diterbitkan

[9] Hamid H, dkk. (2011).Pemetaan Kompetensi dan Pengembangan Mutu Pendidikan SMA di Kota Tidore Kepulauan dan Kabupaten Halmahera Timur (Laporan Penelitian). LPPM Unkhair : tidak diterbitkan.

[10] Muhammad S, dkk. (2011). Pemetaan Kompetensi dan Pengembangan Mutu Pendidikan SMA di Kota Ternate dan Kabupaten Halmahera Tengah (Laporan Penelitian). LPPM Unkhair : diterbitkan.

[11] Rahman A. N, dkk. (2011). Pemetaan Kompetensi dan Pengembangan Mutu Pendidikan SMAdi Kabupaten Halmahera Selatan (Laporan Penelitian). LPPM Unkhair : tidak diterbitkan.

[12] Saubas U, dkk. (2011). Pemetaan Kompetensi dan Pengembangan Mutu Pendidikan SMAdi Kabupaten Kepulauan Sula (Laporan Hibah PPMP 2011). LPPM Unkhair : tidak diterbitkan (2011)

[13] Mulyanta \& Leong. Tutorial Membangun Multimedia Interaktif Media Pembelajaran. Yogyakarta : Universitas Atma Jaya Yogyakarta (2009)
[14] Mohler J.L. Using Interactive Multimedia technologies to improve student understanding of spatially-dependent enginering concept. [Online]. Tersedia: http://www.tech.purdue.edu/cg/ (2011)

[15] Munir. Kurikulum Berbasis Teknologi Informasi dan Komunikasi. Bandung : ALFABETA (2008)

[16] Munadi. Media Pembelajaran. Ciputat : Gaung Persada (GP) Press (2008)

[17] Johnson \& Johnson. (1994). Cooperative Learning in the Classroom. Virginia, Association for Supervision and Curriculum Development.

[18] Slavin, R.E. (2008). Cooperative Learning; Teori riset dan Praktik. Bandung: Nusa Media.

Saprudin*

Program Studi Pendidikan Fisika, FKIP

Universitas Khairun

Saprudin_unkhair@yahoo.com

${ }^{*}$ Corresponding author 


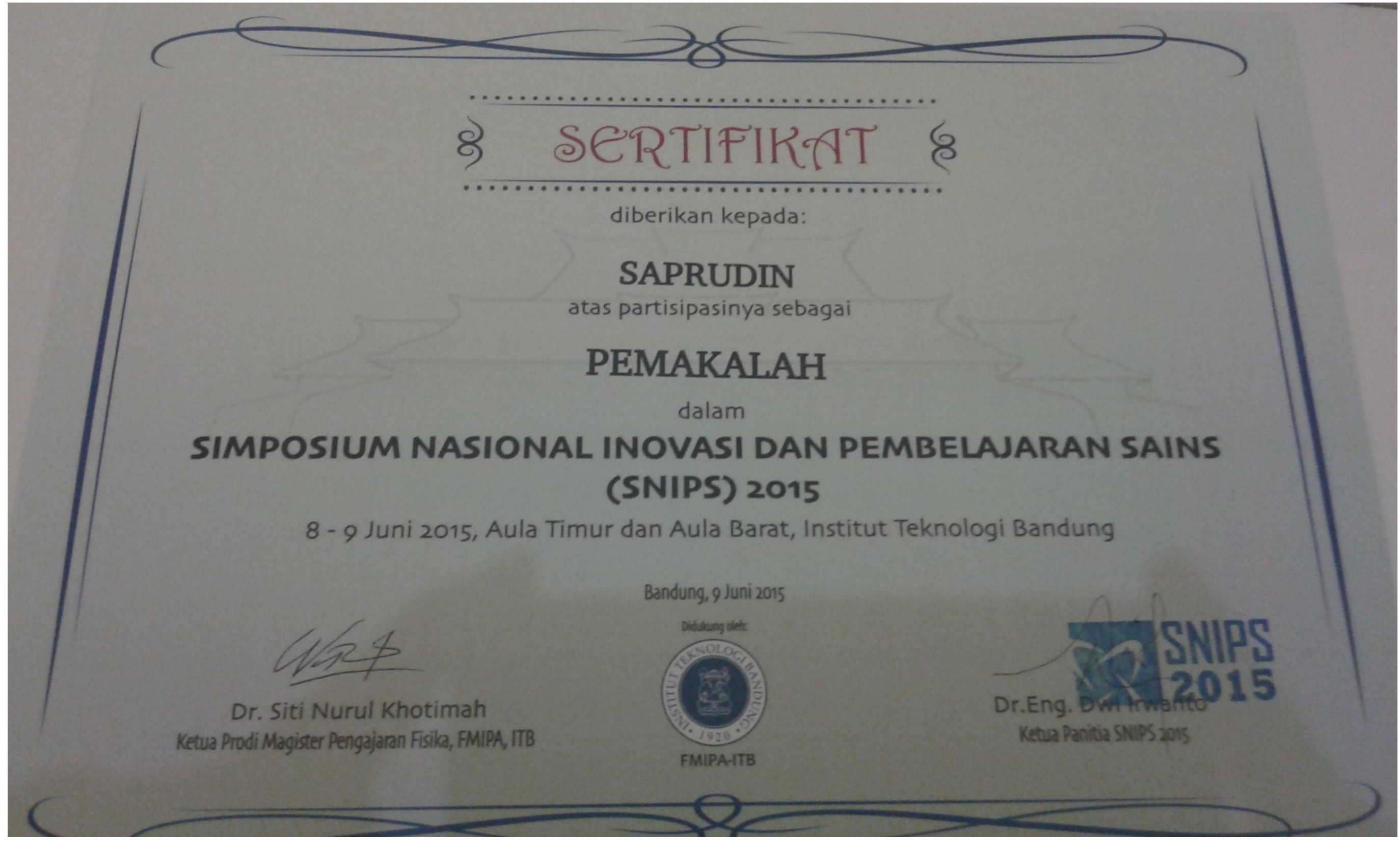

